\title{
Attributes, Benefits and Attitudes: Construct of Zimbabwe Tourism Brand Association Amid Covid-19 Pandemic
}

\author{
Farai Chigora1* Chipo Katsande** \\ *Dept. of Business Science, College of Business, Peace, Leadership and Governance, \\ Africa University, Mutare, Zimbabwe, \\ **Dept. of Computer Science and Information Systems, \\ Manicaland State University of Applied Sciences, Mutare, Zimbabwe, \\ *Correspondence: chigoraf@africau.edu, \\ katsandec@gmail.com
}

\begin{abstract}
The study investigated the factors reflecting and building positive brand association for Zimbabwe tourism destination into the resurgent of COVID-19 pandemic. The focus was on three primary sources of brand association comprising attributes, benefits, and attitudes, which were then assessed to come with the most dominant element(s) for restoring a positive global image. A mixed sequential qualitative to quantitative research design was applied for the study. Qualitative research established sources for the brand association as themes that are acknowledged to be prevailing in Zimbabwe tourism destinations. This was achieved through in-depth interviews with participants who were purposively selected for the study. Further quantitative research was done to understand the most dominant factors for brand association and categorize them as attributes, benefits or attitudes. Results from qualitative research informed the themes for a brand association: perception by the origin of the tourist; references from others; the hospitality of tourism providers; media reports; existing natural resources; accessibility; cultural originality; government policies; and adventure. Quantitative results showed that perception by the origin of the tourist, references from others, the hospitality of tourism providers, media reports, natural resources and accessibility were the most dominating sources of brand association. To conclude, the study brand attitude was discovered as most effective in constructing a lasting association amid and beyond the COVID-19 pandemic. The study recommended innovative partnerships with global tourism agents in various target markets, intensive training of operators and employees in customer care, refurbishing tourism facilities, maximizing E-friendly customer care systems, and maintaining original aesthetic nature.
\end{abstract}

Keywords: Brand Association, Brand Attitudes, Brand Attributes, Brand Benefits, COVID-19, Tourism Destination

\section{How to Cite:}

Chigora, F., \& Katsande, C. (2021). Attributes, Benefits and Attitudes: Construct of Zimbabwe Tourism Brand Association amid Covid-19 Pandemic. International Journal of Business, Management \& Economics. 2(3). 169-183. DOI: https://doi.org/10.47747/ijbme.v2i3.317 


\section{Introduction}

Globally, tourism destinations, including Zimbabwe, are increasingly competing for lucrative tourists' markets even in the resurging of the COVID-19 pandemic. As propounded by Klimek (2013, p. 28), the tourism industry has been identified as one of the most effective pillars for sustaining economic growth. Extending to this view, tourism has improved the welfare of individuals, societies and the government of developing nations (World Bank, 2017). It has become a source of employment, generating national revenues for economic development and improving living standards. In line with the thrust of this study United Nations (2020) has announced that the burgeoning COVID-19 pandemic has negatively affected Sustainable Development Goal 1 (SDG1) as its impact on tourism is threatening more poverty in the future. Undoubtedly, worldwide nations have recognized the tourism industry as a tool for economic development (United Nations World Tourism Organisation, 2017; Christie et al. 2014; World Travel \& Tourism Council, 2017) through various events threaten it and, in this case, pandemics that derail not only revenue generation but tourism brand performance and association.

Zimbabwean tourism destination was once a highly valued attraction in its several source markets, witnessed by a prolonged growth of the industry, especially in the 1980s (Chibaya, 2013). It is in this effort that the Zimbabwe Tourism Authority has introduced a branding and rebranding exercise starting with "Discover Zimbabwe" in the early 1980s followed by "Africa's Paradise" in 1996 to the current "A World of Wonders" in 2011 (Chibaya, 2013; Ndlovu, 2009). Government, businesses and individual commitment to further develop the tourism industry increased tremendously over the years. Various infra-and-superstructures have been established in line with the growing demand for accommodation, travel, and resort activities. Hotels, roads, airports, amenities, and user-customization of natural resources have trended in the industry's peak years. Eventually, these developments had to be sustained by recognizable mechanisms such as destination brand management. Besides the destination mentioned above, sub-sectorial and tourism business brands have been developed for hotels, car rentals, resorts and other sorts.

Reaction to the preceding poor performance of the industry was reflected by a re-branding process three times in three decades. It was mainly linked to the socio-economic and political upheaval that strained the Zimbabwe tourism destination brand and its sub-brands, especially from 1999 to date (Chigora, Ndlovu \& Zvavahera, 2021). The Zimbabwe tourism destination lost its vibrancy year 2000, as proven by a reduction in tourists' arrival from 2,249,615 in 1999 to 1,966,582 in 2000 and 1,880,028 in 2014 (Zimbabwe Tourism Authority, 2011, p.1; 2015, p.10). In light of current mishaps, the destination, like any other in the world, is facing a lifethreatening COVID-19 pandemic. The pandemic has further eroded the attractiveness of the Zimbabwe tourism destination brand adding to the previous negative publicity. It, therefore, inspired research to understand the brand association factors that can be used to retain the vibrancy of the Zimbabwean tourism brand.

In every tourism destination, there are vital contributors to its attractiveness and knowing the right ones to manipulate is a global challenge, especially for Destination Marketing Organisations. The Zimbabwe Tourism Authority has introduced branding in its marketing efforts, but little research has been done on its efficacy to create positive brand associations.

Published by: 
Conceptually, branding has focused on the use of names, symbols, signs, colours and logos to get recognition in a competitive market (American Marketing Association, 2011; Barwise et al., 1990; Keller, 1993), but these elements are not remaining static due to changing events and tastes globally. Therefore, this study needs to continuously adjust and realign branding with new concepts for this study through developing a destination branding concept driven by associations and fused with socio-economic events and resurging pandemics.

Brand association in its origination was classified by Keller $(1993,1998)$ as made up of three categories attributes, benefits and attitudes. Because of this write-up, the brand association becomes an asset that follows a destination when tourists are satisfied to the extent of continuously patronizing a destination into the unforeseeable future. This is in the sense that tourists will become more attached to a destination, and they will visit the destination in times of socio-economic and political downfalls, even in surging pandemics. Little research has been carried out to develop brand association factors to uplift the Zimbabwe tourism destination brand. Therefore, this study was guided by brand association to improve the attractiveness and positive global image of the Zimbabwe tourism destination brand.

Zimbabwe tourism destination brand was changed three times since 1980 (Chigora \& Zvavahera, 2015). Reports and discussions have shown that these regular changes are mainly attributed to pitiable socio-economic and political upheavals in the country (Chibaya, 2013; Ndlovu, 2009; Chigora, Mutambara, Ndlovu, Muzurura \& Zvavahera, 2020). Tourists have shunned Zimbabwe tourism destinations due to the negative news publicity from various sources. Even with the knowledge that the adverse operating environment is the main contributor to the dismal state of the Zimbabwe tourism brand, there is still little information on the factors that are likely to improve the Zimbabwe tourism brand association. The concern is that more followers and associates warrant a brand that is avowed to perform better. In the surging COVID-19 pandemic, it is undisputed and more visible that visitors have also shunned Zimbabwe tourism destination as it has become even more unsafe for any touristic experiences. This study, therefore, was premised on understanding the factors that construct Zimbabwe tourism destination brand association into the COVID-19 resurgent. The focus was on brand attributes, brand benefits and brand attitudes as brand association measurements.

To develop brand association factors for the Zimbabwe tourism destination brand.

To group the identified brand association factors as attributes, benefits or attitudes about Zimbabwe tourism brand. To establish the most dominant sources of brand association for the Zimbabwe tourism destination.

\section{Literature Review}

\subsection{Conceptual review}

Concepts translated to research variables at the methodological stage and beyond (e.g. entrepreneurial motivation; ambition, compelling and facilitating motivation; and performance) are reviewed. 


\section{Brand Association}

Brands have evolved as vital tools that affect consumers in making their day to day buying decisions (Kapferer, 2005). This has transformed livelihoods whereby consumers are now associating themselves with brands rather than available products and services. As Aaker (1991) denoted, the brand association has therefore developed as a concept that expresses what is connected to one's memory of a given brand. In the case of this research, it was on improving a positive memory about the Zimbabwe tourism destination brand. Tuominen (1999) therefore concurred by informing that brand association in its form is any related mental connection to the brand itself that might include issues like product class, attributes, benefits, country of origin and competitors. A tourism destination cannot be excluded from this bandwagon as it can be viewed like any product or service that provides an experience and mental attachment to the tourist. In this regard, a brand association can then play a complementary role with the brand image concept (Herzog, 1963; Keller, 1993). Zimbabwe tourism destination and its brand image have been tarnished over the years. There is a need to develop mechanisms to restore and enhance a positive association in its target markets. There are three main aspects of brand association propounded by Keller (1993): brand attributes, brand benefits, and brand attributes. Brand attributes are those features that can describe a brand and its characteristics that are triggered when the consumer thinks of a brand (Keller, 1998). Brand benefits refer to the values personally attached to the consumer, the brand attributes and what consumers think a brand can do for them (Keller, 2013). Therefore, brand attitude is an overall evaluation of the brand's consumer (Keller 1993). The present literature shows that the concept of tourism destination brand association is limited such that it became the primary driver for this research.

\section{Brand attitude}

In its form, the brand attitude has been viewed as a driver for behavioural attention within the consumption process (Wu \& Wang, 2011). Related to this study is the behaviour and intention to consume the Zimbabwean tourism brand and its offerings. Brand attitude by the consumer has a vital role in the purchasing decision and intention to consume as a dominant determinant (Abzari et al., 2014). As a reaction to the aforementioned, Ukpebor et al. (2008) announced that when a brand is strong, it will affect its customers' attitudes to create a product and brand association. Till \& Busler (2000) retaliated by further postulating that in line with the Theory of Reasoned Action (TRA), an attitude towards performing a particular behaviour is one of the significant predictors for the intention to purchase. Therefore, according to various authors (Abzari et al., 2014; Suki 2016; Kudeshia \& Kumar, 2017), brand attitude is measured by the extent to which consumers can remember a brand; the consumer's preference for the brand; and the consumer's choice of brands, whether consumers prefer brand comparative to another. These aspects have also been considered to build a positive brand association for the Zimbabwe tourism destination brand. This is because, ultimately, attitude towards a brand is a solid driver for energizing the behaviour of the consumer to purchase (Spears and Singh, 2004).

\section{Brand benefits}

According to Franzak et al. (2014), brands go beyond being a communication tool between the consumers and businesses, as they have other extended benefits. Dickson \& Ginter (1987) 
reported that brands have also differentiated one corporate from others in the early years. Thus Zimbabwe tourism destination does not exist in isolation, and it can also benefit in this form by being differentiated from any other. Keller (1993) referred to this as another type of association, mainly as the personal value of a product or service. The brand befits that can be experienced at any time have been classified into three that is, functional benefits, experiential benefits and symbolic benefits (Keller, 1993; Rintoul et al., 2016; Wee \& Ming, 2003).

According to Keller (1993), functional benefits are mainly centred on solving fundamental problems related to the product's attributes. In a tourism destination, there are related physical attributes that can provide this functional benefit. These are more of a utilitarian value as they focus on the functioning of the specific product (Granitz \& Forman, 2015). They are based on product use, and they come from product ownership, making them critical when making a purchasing decision (Porto et al., 2011). Experiential benefits relate to the feeling of using the product and have an impact to satisfy cognitive stimulation (Keller, 1993). They originate from the brand's hedonic and emotional benefits (Granitz \& Forman 2015). Holbrook \& Hirschman (1982) further informed that these benefits are more significant than a service or product attribute. Also, Rintoul et al. (2016) informed that symbolic benefits are related to various needs which require social approval and even personal expression. Information driving an individual's consumption decision stems from symbolic meaning attached to the product (Midgely, 1983). These are the desires for satisfying internal needs like group membership (Park et al., 1986). This also results in consumption for status where products like coffee are purchased for symbolic appeal rather than for functionality (Haire, 1950).

Brand attributes

In a tourism destination like Zimbabwe, there are various attributes of the brand. They refer to any features representing a brand in public or and domain (Keller, 1998). The touristic features, including landforms, culture, people, and artificial and natural structures, are mainly considered. For Zimbabwe tourism destination brand "A World of Wonders" was constructed mainly based on the natural attributes within the destination. Therefore, this calls for a further assessment of any other contributors that can help improve the visibility and attractiveness of the brand.

\section{Destination brand and image}

As announced by Baker \& Cameron (2008), brands play an integrating role, especially in a tourism destination which is a composite of various elements such as natural resources, people and infrastructure. A brand is designed to reflect a specific personality (American Marketing Association, 2011), which was to provide a positive image reflection for this research. Tasci \& Kozak (2006) tried to integrate various components for increased destination brand equity and image creation, as presented in Figure 1 below.

Published by: 


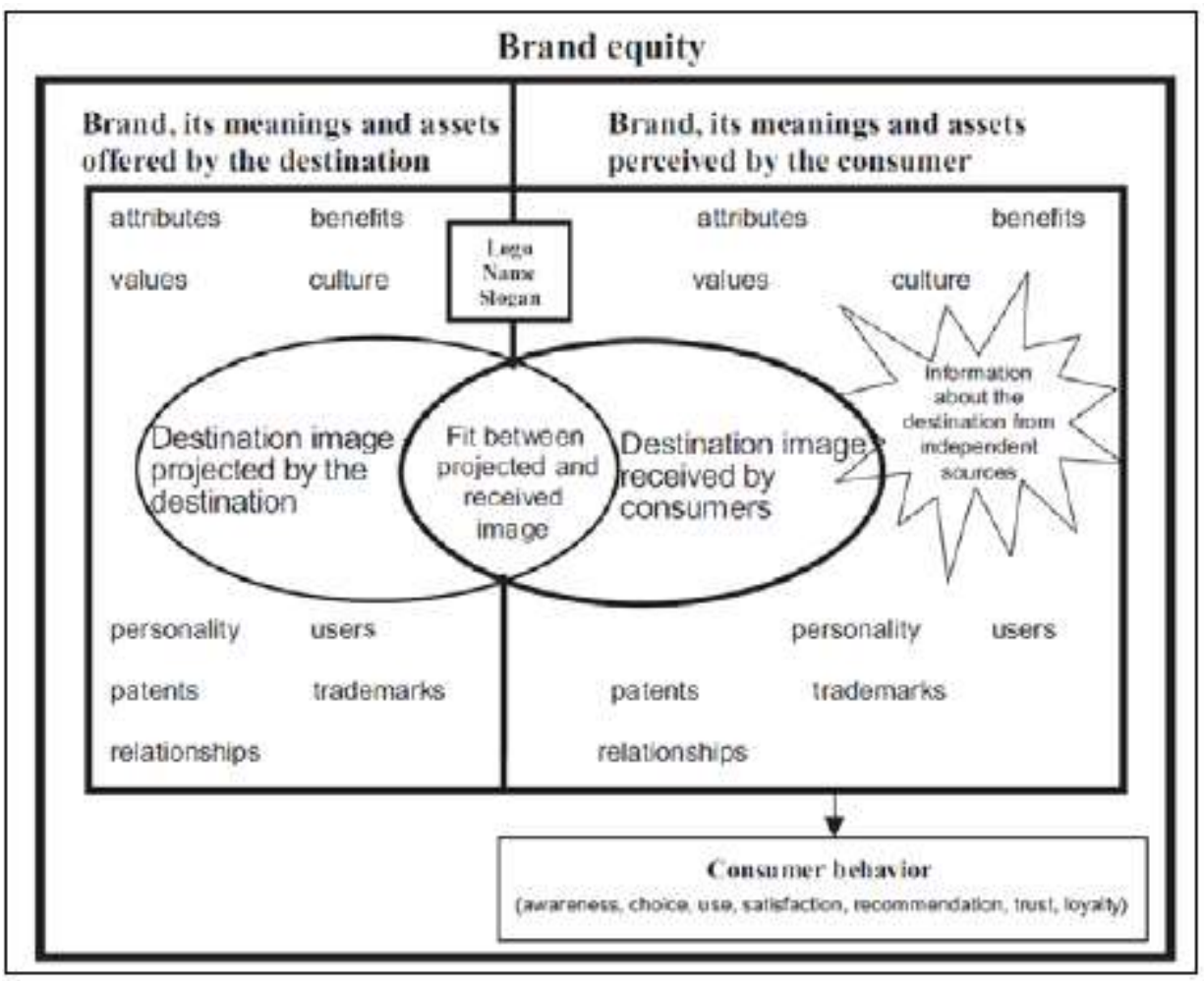

Figure 1. Destination brand associations and image creation

Source: Tasci \& Kozak (2006, p. 313)

The presentation in Figure 1.1 above shows that the projected and perceived brand image is controlled by attributes, benefits and personality (attitude) of both tourism producers and their potential tourists. These have been discussed as the major contributors to a positive brand association (Keller, 1993). Kaplanidou \& Vogt ( 2006) concurred by announcing that brand association variables are critical in improving the image of a tourism destination. The discussion on destination image and destination branding is growing in popularity though still in its infancy (Qu, Kim \& Im, 2011). This reveals that there is still little information on destination branding and image creation, mainly from Zimbabwe's perspective, hence the need to interrogate tourism destination brand association issues. In tourism research, images are more important than any tangible resources because perceptions rather than reality motivate consumers to act or not to act (Gallarza et al., 2002). Molina et al. (2010) informed that image is vital in improving competitiveness in a market. Therefore, the brand image extends to consumers' thoughts and feelings about the brand (Roy \& Banerjee, 2007). Furthermore, Pike (2004) informed on the relationship between brand identity, positioning, and image as presented in Figure 2 below. 


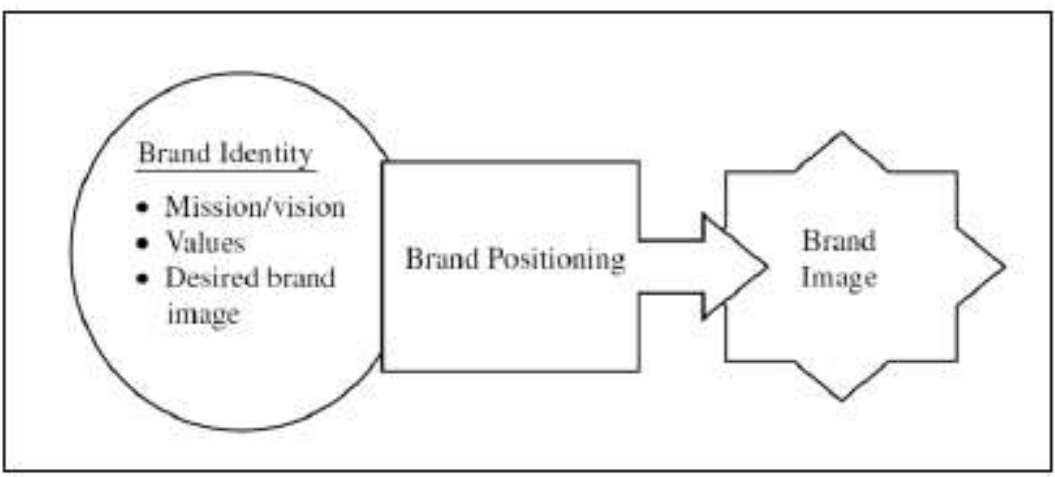

Figure 2 Brand identity, brand positioning and brand image

Source: Pike (2004, p. 75)

As shown in Figure 2 above identity of a brand can help improve its position, which will help improve the brand image. Zanten (2005) announced that it is essential to understand the most viable promotional elements in destination marketing. This study mainly to know elements specific to Zimbabwe tourism brand associations. Hence, the complexity of the tourism product, in combination with the differing requirements of various stakeholders within the destination, pose a threat to the success of destination branding (Baker \& Cameron, 2008).

\section{Research Method}

The study applied a mixed sequential method starting with qualitative and followed by quantitative research. The qualitative research helped in developing the themes for the study from various participants. These participants were selected from the three main sectors of the Zimbabwean tourism industry, which are accommodation (4), travel (3) and resorts (4), totalling $\mathrm{n}=11$. These were selected using purposive judgemental sampling based on the Zimbabwe tourism industry's expertise, experience, and knowledge.

Furthermore, quantitative research was carried out using a survey questionnaire that was developed from themes. The questions in the survey questionnaire were arranged in a 1 to 5 Likert Scale. The range was from 1(Strongly Agree), 2(Agree), 3 (Neutral), 4 (Disagree) and 5(Strongly Disagree). This meant that any responses between 1 and 2.5 were skewed to the positive in agreeing, and any above 2.5 were negative to disagree.

The respondents to the survey were selected using a cluster sampling method, and the clusters comprised of accommodation (30), travel (25) and resorts (20), totalling $\mathrm{n}=81$.

Due to the COVID-19 pandemic, which restricted physical contact, the in-depth interviews were done over the telephone with and range of 22 to 31 minutes per interview. Survey questionnaires were administered online using google forms.

A content analysis was done in order to develop themes from the qualitative data. Quantitative data were analyzed by converting the frequencies into mean values.

\section{Results and discussions}

Published by: 


\subsection{Results from qualitative research}

Qualitative research initiated the study to develop themes of focus concerning Zimbabwe tourism brand association. It, therefore, considered critical views and opinions from the participants $(P 1$, $P 6, P 3, P 5, P 2, P 11, P 8, P 9$, and P7), which are as follows:

P1 "...there is need to understand the perceptions that the tourists have about a tourism destination, and it affected Zimbabwe tourism brand...."

P6 ".....people make references, and they talk about the destination and its brand which is influential in branding....."

P3 "...there is no need to ignore negative media publicity that has manifested in the Zimbabwean tourism industry...."

P5 "...we have a lot of natural resources that we can base our branding on and even market them as our heritage....."

P2 "...If all the service providers maintain their excellent hospitality, the Zimbabwe tourism brand will be uplifted...."

P11 “...we have a rich and unique culture which can be taken as part of our branding beyond borders..."

P8 "...sometimes people will shun the Zimbabwe tourism brand because most attractive places are not accessible by convenient transportation in the country...."

P9 "...government should produce good policies that encourage brand marketing and attraction of tourists..."

P7 "...there are many places for adventure and why not market them for the benefit of the country's brand..."

Therefore the findings from the in-depth interviews produced themes of focus on the factors that can be analyzed for Attributes, Benefits and Attitudes as constructs for Zimbabwe tourism brand association. These factors for focusing on developing a vibrant Zimbabwe tourism brand association are as follows: perception by the origin of the tourist; references from others; the hospitality of tourism providers; media reports; existing natural resources; accessibility; cultural originality; government policies; and adventure.

\subsection{Results from quantitative research}

It was significant to classify the produced themes as attributes, benefits or attitudes as presented in Table 1 below.

Table 1. Classifications according to attributes, benefits and attributes

\begin{tabular}{lll}
\hline Attributes & Benefits & Attributes \\
\hline Accessibility & Adventure & Media reports \\
Cultural originality & - & Hospitality by providers and society \\
Natural resources & - & Reference from others \\
- & - & Perception by the origin of tourists \\
- & - & Government policies \\
\hline
\end{tabular}

A further survey was done on these factors to understand their visibility and effect in the selected tourism sectors. The results from the initial survey are shown in Table 2 below.

Published by: 
Table 2 Responses on the most dominant sources of brand association in Zimbabwe tourism destination

\begin{tabular}{lllll}
\hline $\begin{array}{l}\text { Brand Association } \\
\text { Source }\end{array}$ & $\begin{array}{l}\text { Accommodation Sector } \\
\text { (mean) }\end{array}$ & $\begin{array}{l}\text { Travel Sector } \\
\text { (mean) }\end{array}$ & $\begin{array}{l}\text { Tourism Resorts } \\
\text { (mean) }\end{array}$ & Average mean \\
\hline $\begin{array}{l}\text { Perception by the } \\
\text { origin of the tourist }\end{array}$ & 1.567 & 2.341 & 2.102 & 2.003 \\
$\begin{array}{l}\text { References from } \\
\text { others }\end{array}$ & 1.001 & 1.213 & 1.142 & 1.119 \\
Hospitality & 1.118 & & & 1.111 \\
Media reports & 1.039 & 1.094 & 1.120 & 1.053 \\
Natural resources & 1.987 & 1.112 & 1.007 & 1.696 \\
Accessibility & 1.233 & 2.100 & 1.001 & 1.133 \\
Cultural originality & 1.578 & 1.010 & 1.155 & 2.537 \\
Government policies & 2.103 & 2.011 & 1.021 & 1.577 \\
\hline \begin{tabular}{l} 
Adventure \\
\hline
\end{tabular} & 1.917 & 2.119 & 1.976 & \\
\hline
\end{tabular}

Note. The average means are in a range of 1-5 (1= Strongly Agree; 5=Strongly Disagree)

Source: Field Survey (2021)

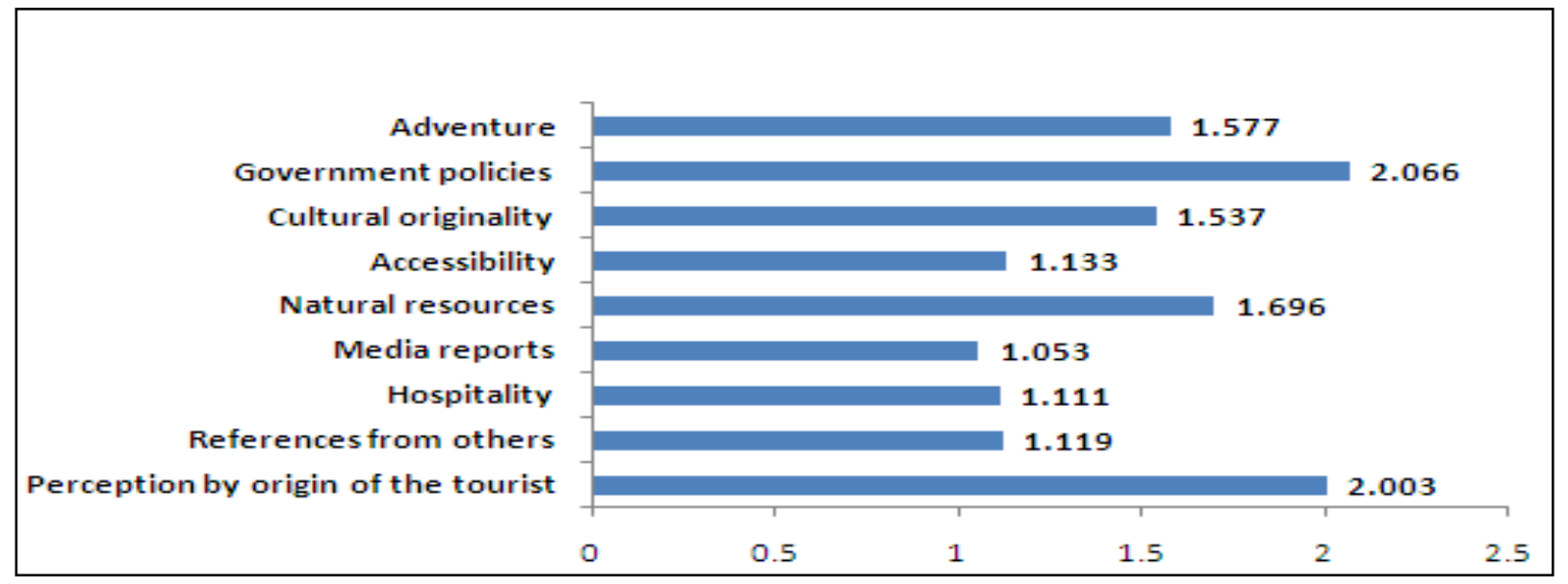

Note. The average means are in a range of 1-5 (1=Strongly Agree; 5=Strongly Disagree)

Figure 3 Average means of responses on the dominant sources of brand association in Zimbabwe tourism destination

Source: Research Survey (2021)

Table 2 and Figure 3 above show that the media reports have the lowest average mean of 1.053. It makes it the most dominant source of brand association and positive image for Zimbabwe's tourism destination brand. This response might be emanating from the fact that globally people follow news from any source of media to make informed consumption and travel decisions. The Zimbabwe tourism destination brand has been subjected to negative media publicity, especially Western traditional markets (Ndlovu, 2009). This destroyed its image, and the Zimbabwe tourism destination brand significantly failed to attract associates (Kaplanidou \& Vogt, 2006). 
The results regarded the hospitality of tourism operators in Zimbabwe tourism destination (1.111) to positively improve image and brand association. This might be because tourism is in the service industry, which is a labour-intensive industry. There is more interaction of people than objects and machinery. The behaviour and attitude of people determine the level of hospitality they provide to the tourists. Zimbabwe as a tourism destination has been rated as one of the destinations with hospitable people. However, the perceived political squabbles have presented wrath and disintegration of the populace in the destination.

The responses also showed a lowest average mean of 1.119 , agreeing that reference from others contributes significantly to a good image and positive brand association. The advent of various communication networks dominated by social media has resulted in people sharing both positive and negative discussions about a destination and its brand more than before. Issues with fights, poverty, excitement and adventure have been significantly shared through word of mouth. Zimbabwe tourism destination brand has suffered due to individuals and groups exchanging negative discussions on the country's perceived negative socio-economic and political affairs (Ndlovu \& Heath, 2013). Amongst those variables with low average means of responses is accessibility (1.133). The reason for such a favourable response might be that people want to be in a place of activity to enjoy tourism. Therefore, there should be roads and other transport network systems in order to improve accessibility. Major renowned destinations in Zimbabwe are accessible through various networks (road, air and rail). However, other potential tourism destinations could escalate the Zimbabwe tourism destination brand's power but are not accessible by any transport network. In some areas, roads are dilapidated with vandalized railway lines and with no airports.

Table 3 Brand associations ranking by Average Means and Source

\begin{tabular}{|c|c|c|c|c|c|}
\hline Zimbabwe & Ranking by & \multicolumn{3}{|c|}{ Assumed Sources of Brand Association } & \multirow{2}{*}{$\begin{array}{l}\text { Most Dominant } \\
\text { Source }\end{array}$} \\
\hline $\begin{array}{l}\text { Tourism } \\
\text { Destination } \\
\text { Brand } \\
\text { Association } \\
\text { Drivers }\end{array}$ & Average Means & Attribute & Benefit & Attitude & \\
\hline Media reports & 1.053 & - & - & $\sqrt{ }$ & Attitude \\
\hline $\begin{array}{lr}\text { Hospitality } & \text { by } \\
\text { providers } & \text { and } \\
\text { society } & \\
\end{array}$ & 1.111 & - & - & $\sqrt{ }$ & Attitude \\
\hline $\begin{array}{l}\text { Reference from } \\
\text { others }\end{array}$ & 1.119 & - & - & $\sqrt{ }$ & Attitude \\
\hline Accessibility & 1.133 & $\sqrt{ }$ & - & - & Attributes \\
\hline $\begin{array}{l}\text { Cultural } \\
\text { originality }\end{array}$ & 1.537 & $\sqrt{ }$ & - & - & Attributes \\
\hline Adventure & 1.577 & - & $\sqrt{ }$ & - & Benefit \\
\hline $\begin{array}{l}\text { Natural } \\
\text { resources }\end{array}$ & 1.696 & $\sqrt{ }$ & - & - & Attributes \\
\hline $\begin{array}{ll}\text { Perception by } \\
\text { the origin of } \\
\text { tourists }\end{array}$ & 2.003 & - & - & $\sqrt{ }$ & Attitude \\
\hline $\begin{array}{l}\text { Government } \\
\text { policies }\end{array}$ & 2.066 & - & - & $\sqrt{ }$ & Attitude \\
\hline
\end{tabular}

Published by: 
Note. The average means are in a range of 1-5 (1=Strongly Agree; 5=Strongly Disagree $)$

Source: Field Survey (2021)

\section{Dominant sources of brand association}

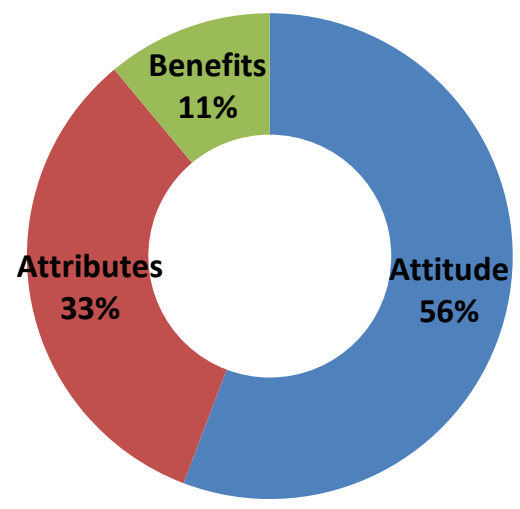

Figure 4 Ranking of the most dominant type of brand association for Zimbabwe tourism destination

Source: Field Survey (2021)

Table 3 and Figure 4 above show the responses on the most dominant sources of brand association in Zimbabwe, specifically looking at the three types used for this study: a benefit, attribute, and attitude. A greater response rate of 56\% shows that attitudes are the main drivers for Zimbabwe tourism destination brand association. This is followed by $33 \%$, claiming that attributes are also a source of brand association, with the least being benefits (11\%). The reason for such a response might be because attitude is developed from sharing and experience. Mainly for Zimbabwe tourism destinations, news publications through national and social media in various source markets have negatively impacted the destination brand association. Therefore, potential tourists have developed a negative attitude from the news and information they received from the media, thus developing a negative brand association.

On the other hand, the Zimbabwe destination has gained popularity from its existing world heritages and other unique forms of flora and fauna. This is because tourism is a highly invisible service, and to assess suitability before a visit, tourists use attributes as a measurement. Likewise, benefits are discoveries on the moment of truth such that tourists become associates when they have turned their perceptions into real-life experiences. Therefore tourism destination marketing organizations in Zimbabwe should balance attitude and attributes in promoting the tourism destination and its brand.

\section{Conclusions and Recommendations}

Published by: 
The study concluded that all the three sources of brand association investigated in this study directly affect the Zimbabwe tourism brand association. These are attributes, benefits and attitudes. However, ranking on the most dominant source, the study revealed that attributes are critical drivers for improved tourism brand association in Zimbabwe. The study recommended innovative partnerships with global tourism agents in various target markets in order to assist in the promotion and showcasing of the tourism attributes in Zimbabwe. Intensive training of operators and employees in customer care will help in improving their level of hospitality and capture more positive referrals. Another issue is the refurbishment of tourism facilities to make them more attractive and user-friendly and maximize e-friendly customer care systems, especially in the COVID-19 era. Also, destination management authorities should invest more in improving accessibility to various touristic destinations. This is a critical element of Zimbabwe tourism destination's attributes. Improvement inaccessibility makes the attractions of a tourism destination identified such that it will be easy to position them on the global market to follow the tourism destination's brand. Lastly, the managers of Zimbabwe tourism destinations should strive to maintain the originality of Zimbabwe's cultural heritage. Culture is unique, and it is rarely copied though easy to dilute. Tourists visit a destination that has a culture that is different from their own. There is a need to maintain the aesthetic state of Zimbabwe's tourism destination as natural resources form the basis of a tourism destination's attractiveness.

\section{References}

Aaker, D. A. (1991). Managing Brand Equity: Capitalizing on the Value of a Brand Name. New York: Free Press.

Abzari, Mehdi, R. Abachian Ghassemi, \& L. Nasrolah iVosta. (2014). Analyzing the Effect of Social Media on Brand Attitude and Purchase Intention: The Case of Iran Khodro Company.

American Marketing Association (2011). Dictionary. Access on 3 April 2011

Baker, M. J. \& Cameron, E. (2008). Critical success factors in destination marketing. Tourism and Hospitality Research, 8 (2), 79-97.

Barwise, P., Higson, C., Likierman, A., \& Marsh, P. (1990). "Brands as 'Separable Assets'", Business Strategy Review, Summer, 43-59

Chibaya, T. (2013). From 'Zimbabwe Africa's Paradise to Zimbabwe A World of Wonders': Benefits and Challenges of Rebranding Zimbabwe as A Tourist Destination. Developing Country Studies, 13 (5), 84-91.

Chigora, F., Ndlovu, J., \& Zvavahera, P. (2021). Zimbabwe Tourism Destination Brand Positioning and Identity through Media: A Tourist's Perspective. Journal of Sustainable Tourism and Entrepreneurship, 2(3), 133-146.

Chigora, F., \& Zvavahera, P. (2015). Attitudinal and Behavioural Loyalty: Zimbabwe Tourism Brand Performance Ascendancy. Business and Management Horizons, 3(2), 52-59.

Published by: 
Chigora, F., Mutambabra, E., Ndlovu, J., Muzurura, J. \& Zvavahera, P. (2020). Towards Establishing Zimbabwe Tourism Destination Brand Equity Variables through Sustainable Community Involvement. African Journal of Hospitality, Tourism and Leisure, 9(5):1094-1110. DOI: https://doi.org/10.46222/ajhtl.19770720-71

Christie, I., Fernandes, E., Messerli, H., Twining-Ward, L. (2014). Tourism in Africa: Harnessing Tourism for Growth and Improved Livelihoods; The World Bank: Washington, DC, USA; pp. 1-12.

Dickson, P.R., \& Ginter, J. (1987). Market Segmentation, Product Differentiation and Marketing Strategy. Journal of Marketing, 51, 1-11.

Franzak, F., S. Makarem, \& Haeran, J. (2014). Design Benefits, Emotional Responses, and Brand Engagement. Journal of Product \& Brand Management, 23 (1), 16-23.

Gallarza, M.G., Gil, I. \& Calderón, H. (2002). Destination Image. Towards a conceptual framework. Annals of Tourism Research, 29 (1), 56-78.

Granitz, N., \& Forman. H. (2015). Building Self-Brand Connections: Exploring Brand Stories Through a Transmedia Perspective. Journal of Brand Management, 22 (1), 38-59.

Haire, M. (1950). Projective Techniques in Marketing Research. Journal of Marketing, 14 (5), 649-656.

Herzog. H. (1963). Behavioral Science Concepts for Analyzing the Consumer. Marketing and the Behavioral Sciences. 76-86.

Holbrook, M.B., \& Hirschman .E.C. (1982). The Experiential Aspects of Consumption: Consumer Fantasies, Feelings, and Fun. Journal of Consumer Research, 9 (2): 132-140.

Kapferer, J.-N. (2005). "The Post-Global Brand", Journal of Brand Management, 12(5), 319-24.

Kaplanidou, K., \& Vogt, C. (2006). Do Sport Tourism Events Have A Brand Image? Proceedings of the Northeastern Recreation Research Symposium, 1-6.

Keller, K. L. (1993). Conceptualizing, Measuring, and Managing Customer-Based Brand Equity. Journal of Marketing. 57, 1-22.

Keller, K. L. (2013). Strategic Brand Management: Building, Measuring, and Managing Brand Equity, 4th Edition. Prentice-Hall.

Keller, K.L. (1993). Conceptualizing, Measuring, and Managing Customer-Based Brand Equity. Journal of marketing. 57 (January): 1-22

Keller, K.L. (1998). Strategic Brand Management. Building, Measuring and Managing Brand Equity, New Jersey, Prentice-Hall.

Klimek, K. (2013). Destination Management Organisations And Their Shift To Sustainable Tourism Development. European Journal of Tourism, Hospitality and Recreation, 4 (2), 27-47.

Published by: 
Kudeshia, C. \& Kumar, A. (2017). Social eWOM: does it affect the brand attitude and purchase intention of brands? Management Research Review, 40(3), 310-330. DOI: 10.1108/MRR-07 2015-0161.

Midgley, D.F. (1983). Patterns of Interpersonal Information Seeking for the Purchase of a Symbolic Product. Journal of Marketing Research, 20 (1), 74-83.

Molina, A., Gómez, M. \& Martín-Consuegra, D. (2010). Tourism marketing information and destination image management. African Journal of Business Management, 4 (5), 722728.

Ndlovu, J. (2009). Branding is a strategic tool to reposition a destination: A survey of key tourism stakeholders in Zimbabwe (Doctoral dissertation, University of Pretoria). The University of Pretoria.

Ndlovu, J., \& Heath, E. (2013). Re-branding of Zimbabwe to enhance sustainable tourism development: Panacea or Villain. Academic Journals, 1 (12), 947-955.

Park, C.W., B.J. Jaworski, \& MacInnis. DJ (1986). Strategic Brand Concept-Image Management. Journal of Marketing, 50 (3), 135-145.

Pike, S. (2004). Destination Marketing Organizations. Oxford: Elsevier.

Porto, R.B., J.M. de Oliveira-Castro, \& Seco-Ferreira. DC (2011). What Consumers Say and Do: Planned and Actual Amounts Bought in Relation to Brand Benefits. The Service Industries Journal, 31 (15), 2559-2570.

Qu, H., Kim, L.H. \& Im, H.H. (2011). A model of destination branding: Integrating the concepts of the branding and destination image. Tourism Management, 32 (2011), 465-476.

Rintoul, D., H. Hajibaba, \& S. Dolnicar. (2016). Comparing Association Grids and 'Pick Any' Lists for Measuring Brand Attributes. International Journal of Market Research 58 (6), 779-794.

Roy, D., \& Banerjee, S. (2007). Caring strategy for integration of brand identity with brand image. International Journal of Commerce and Management, 17(1/2), 140-148.

Spears, N. and Singh, S. N. (2004). Measuring Attitude toward the Brand and Purchase Intentions. Journal of Current Issues \& Research in Advertising, 26(2), 53-66. DOI: 10.1080/10641734.2004.10505164.

Suki, N. (2016). Green Product Purchase Intention: Impact of Green Brands, Attitude, and Knowledge. British Food Journal. Emerald Group Publishing Limited, 118(12), 28932910. DOI: 10.1108/BFJ-06-2016-0295.

Tasci, A.D.A. \& Kozak, M. (2006). Destination brands vs Destination images: Do we know what we mean? Journal of Vacation Marketing, 12 (4), 299-317.

Till, B. D. \& Busler, M. (2000). The Match-Up Hypothesis: Physical Attractiveness, Expertise, and the Role of Fit on Brand Attitude, Purchase Intent, and Brand Beliefs. Journal of

Published by: 
$\begin{array}{llllll}\text { Advertising. } \quad \text { Taylor \& } \quad \text { Francis } \quad \text { Group, } & 29(3), & 1-3 . & \text { DOI: }\end{array}$ 10.1080/00913367.2000.10673613.

Tuominen, Pekka. (1999). Managing Brand Equity. Turku School of Economics and Business Administration. LTA 1 (99). p: 65-100.

Ukpebor, P., Ipogah, B., Aronsson, B., \& Svensson, M. (2008). A Study to Indicate the Importance of Consumer Based Brand Equity on Consumer Perception of Brand: A Case Study of Fast Food Restaurants.

United Nations (2020). Policy Brief: COVID-19 and Transforming Tourism. https://unsdg.un.org/sites/default/files/2020-08/sg_policy_brief_covid19_tourism_august_2020.pdf

United Nations World Tourism Organisation (2017). Annual Report 2016; UNWTO: Madrid, Spain.

Wee, TTT, \& M.C.H. Ming. (2003). Leveraging on Symbolic Values and Meanings in Branding. Journal of Brand Management 10 (3), 208-218.

World Bank Group (2017). Tourism for Development. 20 Reasons Sustainable Tourism Counts for Development. https://openknowledge.worldbank.org/bitstream/handle/10986/28388/119954-WPPUBLIC-SustainableTourismDevelopment.pdf.

World Travel \& Tourism Council (2017). Travel \& Tourism Economic Impact: World; WTTC: London, UK.

Wu, P., C. \& Wang, Y., C. (2011). "The influences of electronic word-of-mouth message appeal and message source credibility on brand attitude", Asia Pacific Journal of Marketing and Logistics, 23(4), 448-472.

Zanten, R. V. (2005). Drink Choice: Factors Influencing the Intention to Drink Wine.

Zimbabwe Tourism Authority. (2011). Tourism Trends Annual Report. Harare, Zimbabwe.

Zimbabwe Tourism Authority. (2015). Tourism Trends Annual Report. Harare, Zimbabwe .

\section{Copyrights}

Copyright for this article is retained by the author(s), with first publication rights granted to the journal.

This is an open-access article distributed under the terms and conditions of the Creative Commons Attribution license (http://creativecommons.org/licenses/by/4.0/) 